\title{
$\operatorname{coO}-20 \% 2-3$
}

\section{THE DYNAMICS OF CHEMICAL REACTIONS}

PROGRESS REPORT

\author{
YUAN TSEH LEE
}

UNIVERSITY OF CHICAGO

CHICAGO, ILLINOIS

January 1, 1972 - December 31, 1972

Prepered for the U. S. Atomic Energy Commission Under Contract No. At(11-1)2092

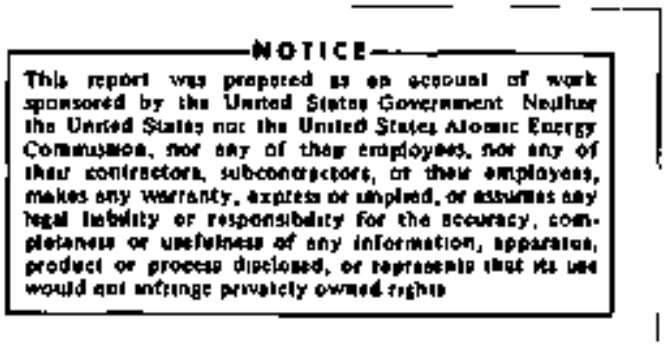




\section{DISCLAIMER}

This report was prepared as an account of work sponsored by an agency of the United States Government. Neither the United States Government nor any agency Thereot, nor any of their employees, makes any warranty, express or implied, or assumes any legal liability or responsibility for the accuracy, completeness, or usefulness of any information, apparatus, product, or process disclosed, or represents that its use would not infringe privately owned rights. Reference herein to any specific commercial product, process, or service by trade name, trademark, manufacturer, or otherwise does not necessarily constitute or imply its endorsement, recommendation, or favoring by the United States Government or any agency thereof. The views and opinions of authors expressed herein do not necessarlly state or reflect those of the United States Government or any agency thereof. 


\section{DISCLAIMER}

Portions of this document may be illegible in electronic image products. Images are produced from the best available original document. 


\title{
TECHNICAL PROGRESS REPORT
}

AEC GRANT AT (I]-1) 2092 MOD 1-1

January 1, 1972 - December 31, 1972

\begin{abstract}
Substantiol progress has been made on all five. (5) programs-listed-

below:

1.) Dynomics of atom molecule reactions.

2.) Intermolecular potentials.

3.) Inelostic scattering of atoms and molecules.

4.) High energy collisions --- hot afom chemistry.

5.) Coltisions of metastable atoms and molecules.

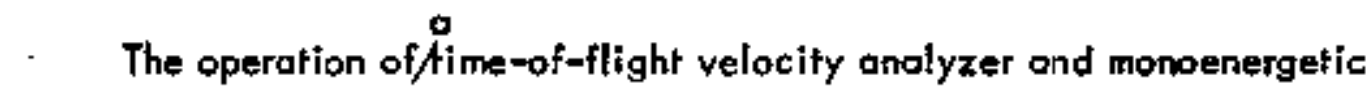
metastable atom beam source added axperimental sophistication.
\end{abstract}




\section{TECHNICAL PROGRESS REPORT}

AEC GRANT AT-(11-1) 2092 MOD I-1

JANUARY 1, 1972 - DECEMBER 31, 1972

1. Approximale percentoge of time the prineipol investigator has devoted to the project: $60 \%$.

The amount of effort which is expected to be devoled during the remainder of the current term: $60 \%$.

II. Programs undertaken during the current kerm;

A. Dynomics of atom molecule reactions

During this contract period, we have put into operation a time-of-flight velocily onalyzer for praduct velocity distribution measurements. Product velocify distributions were measured for the following reactions

1) $\mathrm{F}+\mathrm{D}_{2} \rightarrow \mathrm{DF}+\mathrm{D}$

2) $\mathrm{F}+\mathrm{C}_{2} \mathrm{H}_{4} \rightarrow \mathrm{C}_{2} \mathrm{H}_{3} \mathrm{~F}+\mathrm{H}$

3) $\mathrm{F}+\mathrm{C}_{4} \mathrm{H}_{8} \rightarrow \mathrm{C}_{3} \mathrm{H}_{5} \mathrm{~F}+\mathrm{CH}_{3}$ (1-, cis-2-, trans-2-

$$
\rightarrow \mathrm{C}_{4} \mathrm{H}_{7} \mathrm{~F}+\mathrm{H}
$$
and iso-butene)

4) $\mathrm{F}+\mathrm{C}_{6} \mathrm{H}_{6} \rightarrow \mathrm{C}_{6} \mathrm{H}_{5} \mathrm{~F}+\mathrm{H}$

In reaction 1), different vibrational states of DF are resolved in velocity space, which confirm our earlier anolysis an angular distribution. In reaction 2), our experiment clearly establishes the fact that in controst to RRKM theory, the internal energy distribution is nol statistical during the lifetime of collision complex. Similar phenomens were observed in reaction 3), 4) and many other reactions of fluorine otoms with unsaluroted hydrocarbons, Results of $F+D_{2}$ work have been described in the Ph. D thesis of T. P. Sehafer; further work at o different collision energy will be performed in the next period. The work of 
reactions of fluorine atom and unsaturated hydrocarbons, which is mainly designed to study the process of intramolecular energy transfer and unimolecular decompositions, has been summarized in six papers and has been submitted for publication in J. Chem. Phys. These six popers are listed in Section III. B. [Papers submitted for publication: No. 4, 5, 6, 7,8 and 9.] The preprints of these popers are included in this progress report. B. Intermolecular potentiols

Differential cross sections of scattering of para $-\mathrm{H}_{2}$ with para- $\mathrm{H}_{2}$ were measured at low collision energy. The effect of Bose stotistics which para- $\mathrm{H}_{2}$ followed was observed in differential cross sections. The intermolecular potential was obtained for $\left(\mathrm{H}_{2}\right)_{2}$. The work is summarized in a paper listed in Section V. A. [Poper published during contract period, No. 9.]

$\mathrm{Ne}_{2}$ potential was further investigated at lower collision energy and now we have a reliable potential which gives good agreement with transport properties, solid properties, second virial coefficient as well as spectrascopic observation. The work is summarized in a paper listed in Section III B. [Paper submitted for publication, No. 3.]

We have also started the project of studying the inferaction with open shell atoms. The first two systems studied are $\mathrm{H}_{2}+1$ and $\mathrm{Ne}+1$. The energy of interaction for $\mathrm{H}_{2} \mathrm{I}$ was found to be much smoller than the value used in trapectory calculation by Richard Porter. The Nel interaction is essentially the some as that of $\mathrm{NeXe}$. The monuscript is under preparation for these results. Also, see Section III. B, No, 1 and No. 2. 
C. Inelastic seottering of oloms and molecules

We have successfully observed single ratational quantum tronsition in. $H D(J=0)+\mathrm{He}_{e} \rightarrow \mathrm{HD}(\mathrm{J}=1)+$ He process from the measurements of velocity of scattered HD. The cross section of this process appeors to be smaller thon $1 t^{2}$ at collision energy of $0.4 \mathrm{kcal} /$ mole. This value is much smoller than the recent theoretical calculation of Jakayanagi $\left(5 \mathrm{I}^{2}\right)$. The main reoson for the discrepency is due to the lack of relitble information on potential between $\mathrm{He}$ and $\mathrm{H}_{2}$ molecule rather than inadequacy of theory. Since we have obtoined this part of potential from elastic differential cross section meosurements, this process will be extensively investigated theoretically.

For tronslational-rotational energy transfer, as well as for the study of reaction dynamics, a ratational state selector for dipolor diatomic molecules has been constructed during this period The state selector is just in the process of testing with $\mathrm{HCl}$ molecules.

D. High energy collisions --- hot atom chemistry

Reaction of $\mathrm{I}+\mathrm{HCl} \longrightarrow \mathrm{H}+\mathrm{ICl}$ has been studied in this period. The threshold observed for this reaction is somewhat higher than endoergicity, and the cross section is only $\sim 10^{-20} \mathrm{~cm}^{2}$ even ot $5 \mathrm{kcal} /$ mole above the threshold of this reaction. Experimental results are under analysis.

We have also made significant progress in the study of collisional dissociation. Angutar distributions and energy distributions for both positive and negalive ions have now become possible. After completion of this work, it will give us the opportunity of understonding the dynamies of collisional dissaciation more thoroughly. 
E. Collisions of metastable atoms and molecules

The beam of monoenergetic metastable beam source has been successfully constructed and operated. We have studied the scottering of melastable He with ground sfote He and Ar, metastable Ar with Ar. Differential cross sections measured provides information on resonant excitotion energy transfers, as well as Penning ionization proçess in $\mathrm{He}^{\star}+\mathrm{Ar} \rightarrow \mathrm{He}+\mathrm{Ar}$ as a function of impact parameter. Preliminary results have been published, Secrion III, A. [Paper published during contract period, No. 7.] Preprints of this paper are included in this report. [Reprints were not available at the time of preparation of this report At present we are trying to improve our metastabie beom source both in intensity and selectivity. A quenching lamp is now installed for removing $\mathrm{He}^{*}(\mathrm{~s})$ from the beam, such that pure $\mathrm{He}^{*}{ }^{3} \mathrm{~s}$ ) remains.

III. Publicotion List

A. Papers published during contract period.

I. Intermolecular Potentials. from Crossed Beam Differential Elastic Scattering Mecosurements IV. Ar + Ar, J. M. Parson, P. E. Siska and Y. T. Lee J. Chem. Phys, 56, 1511 (1972).

2. Reactive Scattering of Atoms and Molecules: Crossed Mblecular Beam Experiments Y.T. Lee, VIIth ICPEAC Book of Invited Talk and Progress Reports, North-Hollond Publishing Co. (1972) p. 357.

3. Crossed Mblecular Beam Study of $\mathrm{F}+\mathrm{C}_{2} \mathrm{H}_{4}, \mathrm{C}_{2} \mathrm{D}_{4}$, J. M. Porson and Y. T. Lee, J. Chem, Phys. 하, 4658 (1972). 
4. Hyperthermal Xe Baam from Free Jets of $1 \%$ Xe and $99 \% \mathrm{H}_{2}$.

H. Haberland and F. P. Tully, VIII Intemational Symposium of Rarefied Gas Dynomics, Polo Alto, Colifornio (1972).

5. Intermolecular Potentials From Crossed Beam Differential Elastic Scattering Measurements V. The Attractive Well of $\mathrm{He}_{2}$ J. M. Farrar and Y.T. Lee, J. Chem. Phys. 56, 5801 (1972).

6. Intermalecular Potenticls from Crossed Beam Differential Elostic Scaltering Measurements VI. Atoms and Diatomic Molecules. $\mathrm{Ar}+\mathrm{N}_{2}$ Ar $+0_{2}, \mathrm{Kr}+\mathrm{N}_{2}$ and $\mathrm{Kr}_{\mathrm{r}}+\mathrm{0}_{2}$, F. P. Tully and Y. T. Lee, J. Chem. Phys. 57, 866 (1972).

7. Differential Cross Sections for Mefastable He and A, H. Hoberland, C. H. Chen and Y, T, Lee, Atomic Physics III. Plenum Publishing Co. (1972) p. $35 \%$.

8. Comments on the Interatomic Potential for Argon, H. J. M Hantey, J. A. Borker, M Xlein, J. M Parson and Y. T. Lee, J. Mol. Phys. 24, 11 (1972). 9. Intermolecular Potentials from Crossed Beam Differential Elastic Scattering Measurements VII Para- $\mathrm{H}_{2}+$ Para-H $\mathrm{H}_{2}$ J. M. Farrar and Y. T. Lee, J. Chem. Phys. $57,5492(1972)$

B. Papers submitted for publication (to appear in 1973 Joumals)

1. Spectroscopic Information on Homonuclear Inert Gos Diatomics, Kate K. Docken ond Trudy P. Schafer; J. Mol. Spectroseopy (1973).

2. Comment on Inert Gas Potentials for Mixed Interactions, T. P. Sehafer and Y. T. Lee, J. Chem. Phys. 
3. Neon Interatomic Potentia's from Scattering Dato and Crystalline Properties, J. M. Farror, Y.T. Lee, V. V. Goldmen and M. L. Klein, Chem, Phys. Letters.

4. Unimolecular Decomposition of the Long-Lived Complex Formed in the Reaction of $F+C_{4} H_{8}$ John $M$ Parson, Kosuke Shobatake, Yuan T. Lee and Stuart A. Rice, J. Chem. Phys.

5. The Unimoleculor Decomposition of Long-Lived Complexes of Fluorine and Substituted Mono-Olefins, Cyclo Olefins and Dienes, Kosuke Shobatake, Y. T. Lee and Stuart A. Rice, J. Chem, Phys.

6. The Laboratory Angulor Dependence and the Recoil Energy Spectrum of the Products of the Reaction $F+C_{6} D_{6} \rightarrow D+C_{6} D_{5} F$, John M. Parson, Kosuke Shobotoke, Yuan T. Lee and Stuark A. Rice, J. Chem, Phys.

7. The Reactions of $F$ Atoms and Aromatic and Heterocyclic Molecules: Energy Distribution in the Reaction Complex, Kosuke Shabatake, Yuan $\mathbf{T}$. Lee and Stuart A. Rice, J. Chem. Phys.

8. A Classical Model of Collision Induced Vibration-Translation Energy Partitioning, K. Shobatake, Stuart A. Rice and Yuan T. Lee, J. Chęm, Phys.

9. Substitution Reactions of Fluorine Atoms with Unsaturated Hydrocarbons: Crossed Molecular Beam Studtes of Unimolecular Decompositions, John M. Parson, Kosuke Shobarake, Yuan T. Lee and Stuart A. Rice, Discussions Farradioy Soc. 
C. Ph. D. Thesis completed during controct period

1. Crossed-Molecular-Beam Scattering Studies with a Mass Spectrometric Delector, Ph. D. Thesis, John Morris Parson, The University of Chicago, Chicogo, Illinois, June 1972.

2. Crossed Molecular Beam Studiés of .Elástic and Réacitive Scattering, Ph. D. Thesis, Trudy-Porter Schofer, The University of Chicogo, Chicago, Illinais, December 1972.

D. Seminors and Conference speeches given during contract period

1. Recent Molecular Beam Studies of Chemical Reactions, Physical Chemistry Seminor, Univ. of California, Berkeley, California, Feb. 1972.

2. Reactive Scattering of Atoms and Molecules Chemistry Department Seminer, National Taiwan Univ., Taiwan, CHINA, March 1972.

3. Intermolecular Potentials, Chemistry Department Seminar, National Tsinghua University, Taiwan, CMINA, April 1972.

4. Study of Reactive Scattering by Crossed Moleculor Bearn Method, Special Seminar Sponsored by the Chinese Chemical Society, Toiwan, CHINA, May 1972.

5. Reactive Scattering, Gordon Research Conference, Principal Sepaker, New Hampshire, July 1972.

6. Molecular Beam Chemical Kinetics, Physical Chemistry Seminar, University of Illinois, Ubana, Illinois, Oekober 1972. 
7. Atomic and Molecular Processes, Chemistry Division Seminor

National Bureau of Standards, December 1972.

IV. List of Personnel working on the project in addition to the author:

NAME POSITION

Hellmut Haberland Research Associate Fellowship, Forschungs-Gemeinschoff, Germony

John M Parson Research Assistant NSF Troinee

Research Associate* ACS - PRF

Trudy P. Schafer Research Assistont

Research Associate*

Albert $Y$. Wong Research Assistant

Research Assistont

Frank P. Tully

James Forror

Winston C. Chen

Chuck C. $\mathrm{Ng}$

Cindy Denley
Research Assistont

Respearch Assistant

Research Assistant

Under Graduate

(Summer Student)
Fannie and John Hertz Foundation Groduate Fellow

Camille and Henry Dreyfus Foundation

$\operatorname{AEC}-A T(t 1-1) 2092$

ARPA Student

University of Chicago

AEC-AT(11-1) 2092

AEC-AT(1 I-1) 2092

NSF - Summer Research

Porticipont
N5F - Graduate Fellow

Change of status during controct period. 